\title{
Lymph Node Pain
}

National Cancer Institute

\section{Source}

National Cancer Institute. Lymph Node Pain. NCI Thesaurus. Code C78440.

A painful sensation in a lymph node. 